DOI: $10.17707 /$ AgricultForest.61.4.19

Otilija MISECKAITE ${ }^{1}$

\title{
EFFECTS OF HUMUS THICKNESS LAYER ON DRAINAGE RUNOFF
}

\begin{abstract}
SUMMARY
The article presents the influence of fluctuation of the main climatic factors over time on drainage runoff, the analysis of drainage runoff distribution in the course of a year. The size of drainage runoff depends on meteorological conditions of the year, the most important of which are the precipitation quantity and air temperature, however, the soil characteristics conditions are very important factor too. The impact of humus on heavy-textured soil is multiple, since not only moisture regimes, biological activity, sorption capacity, chemical and biological characteristics, stability of plant nutrition are related with its quantity. This study presents drainage runoff dynamic in two contrasting humus thickness layers systems (in soil with thickened (up to 40-50 cm) humus layer and with humus layer of natural thickness $(20-30 \mathrm{~cm})$ during various seasons) during 1989-2012 years of a long-term experiment in Centre Lithuania. It was found that the thicker layer of soil humus substantially improves the drainage performance. The field with the thickened humus content drainage runoff ranged higher amplitude than the field in all seasons, with a natural layer of humus. It is determined that the lowest quantity of precipitation in the researched territory during the research period is in spring and winter but the highest - in summer and autumn. During the research period the highest drainage runoff in the field with thickened humus layer was during winter season (46\%), in the field with humus layer of natural thickness - in winter and spring almost the same (32$33 \%)$.
\end{abstract}

Keywords: runoff, drainage, humus, temperature, precipitation.

\section{INTRODUCTION}

Global warming is expected to lead to a more vigorous hydrological cycle, including more total rainfall and more frequent high intensity rainfall events. The processes involved in the impact of climate change on soil erosion by water are complex, involving changes in rainfall amounts and intensities, number of days of precipitation, ratio of rain to snow, plant biomass production, plant residue decomposition rates, soil microbial activity, evapo-transpiration rates, and shifts in land use necessary to accommodate a new climatic regime (Nearing et al., 2004). Air temperature and moisture content generally determines the duration of

\footnotetext{
${ }^{1}$ Otilija Miseckaite (corresponding author: Otilija.Miseckaite@asu.lt), Aleksandras Stulginskis University, Institute of Water Resources Engineering, LITHUANIA.

Paper presented at the $6^{\text {th }}$ International Scientific Agricultural Symposium "AGROSYM 2015"

Note: The authors declare that they have no conflicts of interest. Authorship Form signed online.
} 
plants vegetation and development, size of yield. The influence of meteorological conditions occurs not only directly on the yield, but also on its quality indicators (Kupcinskas et al., 2003). The quality and quantity of chard depended on soil properties (Knezevic et al., 2014). Agricultural drainage - the important nonpoint source pollution of surface waters (Sims et al., 1998). Soil system budgets were considered to possess the highest uncertainty of the three budgeting approaches, since nutrient losses via leaching, runoff, volatilization, and denitrification are classified as the most uncertain nutrient flows (Oenema et al., 1999). Phosphorus losses were found to be much more dependent on the soil texture and soil phosphorus and humus content (Buciene et al., 2007). Humus has beneficial effects on nutrient uptake, transport and availability to plant and it enhances stress tolerance (Celik et al., 2010). In Lithuania, artificial drainage is a common agricultural practice. The country remains one of the most extensively drained in the world. The total drained land area occupies $47 \%$ of the country's land area and $86 \%$ of the agricultural land area, of which $87 \%$ is tile-drained. Although the introduction of drainage has improved the quality of agricultural land, the benefits of drainage are associated with many changes in the local environment (Povilaitis et al., 2015). Secondary drainage impact of groundwater outflow can affect drainage design and form a pathway for nutrient loading in agricultural areas (Turunen and al., 2015). Especially important indicator of drainage functioning - water runoff dynamics, that parameters depend on climatic and soil characteristics.

\section{MATERIAL AND METHODS}

The investigation was carried out in the experimental fields of Aleksandras Stulginskis University in 1989-2012, Lithuania. In the territory of investigations the soil was calcareous deeper gleyic leached soil, calcar - Hypogleyic Luvisol, according to mechanical composition - loam of medium-heaviness and light loam. Soil volume mass in the layer of $1 \mathrm{~m}$ varies from 1.3 to $1.7 \mathrm{~g} / \mathrm{cm}^{3}$, porosity - from 32.0 to $50.9 \%$, hygroscopic moisture - from 0.95 to $2.36 \%$, filtration coefficient in arable layer $-0.31-0.94 \mathrm{~m} /$ day. Scheme of the experiment: field No. I with thickened layer of $40-50 \mathrm{~cm}$; field No. II - control, with natural humus layer of 20-30 cm. Meteorological conditions (winter XII-II, spring III-V, summer VI-VIII, autumn IX-VIII) were assessed, following the data of Kaunas Meteorological Station, located $0.5 \mathrm{~km}$ from experimental field. The layer height $\mathrm{mm}$ of drainage runoff was calculated by the following formula:

$$
h=\frac{Q \cdot t}{A \cdot 1000},
$$

here $Q$-drainage runoff $1 \mathrm{~s}^{-1} ; t$ - time s; $A$ - drainage area ha.

The treatment effects were compared using the least significant difference test at the level of $95 \%\left(\mathrm{LSD}_{05}, p-0.05\right)$ probability. 


\section{RESULTS AND DISCUSSION}

Analysing the drainage runoff during a twenty-three year period between the annual values outside with the artificially thickened humus content (up to 50 $\mathrm{cm}$ ) and in the control field, with natural humus content (up to $30 \mathrm{~cm}$ ), a statistically significant difference $(\mathrm{p}<0.05)$ was defined. While analysing annual drainage runoff in fields I and II , about 30\% higher drainage runoff from the field with increased humus quantity is observed (from 113\% in 1998 to $9 \%$ in 2009) (Fig.1).

While analysing the dependence of size of annual drainage runoff on annual amount of precipitation, annual temperature and evaporation individually, it was determined that the greatest impact on drainage runoff outside with thickened humus layer is had by precipitation, as in control field. Correlation relation is moderate ( $\mathrm{r}=0.40$ (II field), $\mathrm{r}=0.46$ (I field)). By correlation analysis the result showed that there were significant relationship $(p<0.05)$ between the runoff and precipitation in I field. There was no significant relationship between the runoff and rainfall in II field, but the rainfall had impact on the runoff.

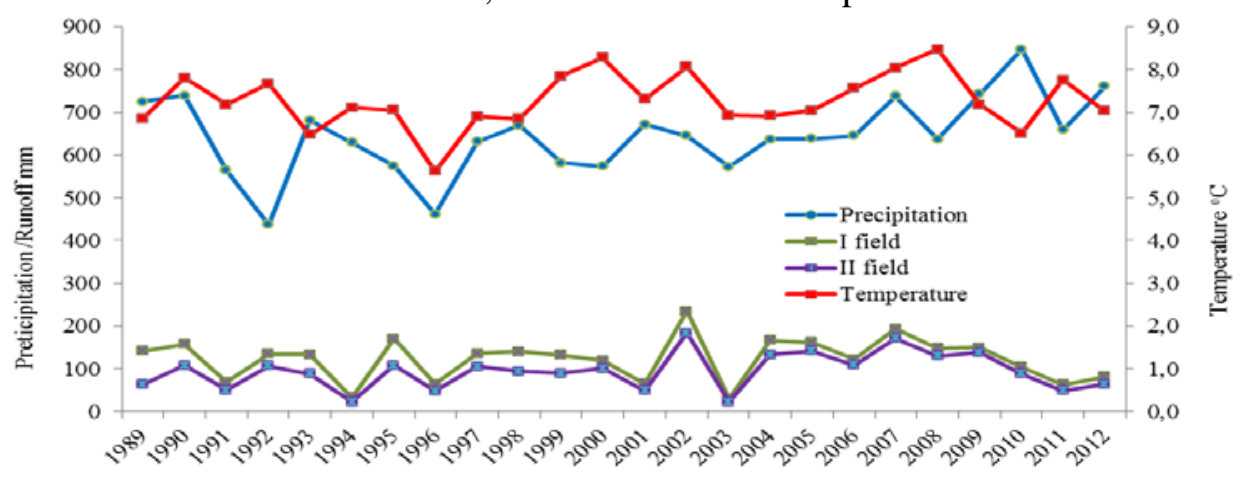

Fig. 1. Annual precipitation, temperature and drainage runoff

Following the method of group linear regression, the dependence of height of drainage runoff on participation, evaporation and temperature was analysed. While analysing field I (with thickened humus layer), the correlation coefficient $r=0.49$ was obtained. A similar correlation coefficient was obtained, when analysing the dependence of drainage runoff under natural humus $(\mathrm{r}=0.46)$.

During the research period temperature was close to climatic norm during all seasons. Average temperature of spring months is characterized by the most significant increase $\left(0.3^{\circ} \mathrm{C}\right.$, Fig. 2). Correlation is moderate during all seasons, thus, the increase of temperature trend is clearly observed. These results are consistent with forecasted results of global temperature increase, which state that the average temperature in 2030 should be higher by $1^{\circ} \mathrm{C}$ than in the end of twentieth century, i.e., it should increase by $0.033{ }^{\circ} \mathrm{C}$ annually (Bukantis et al., 2005). 


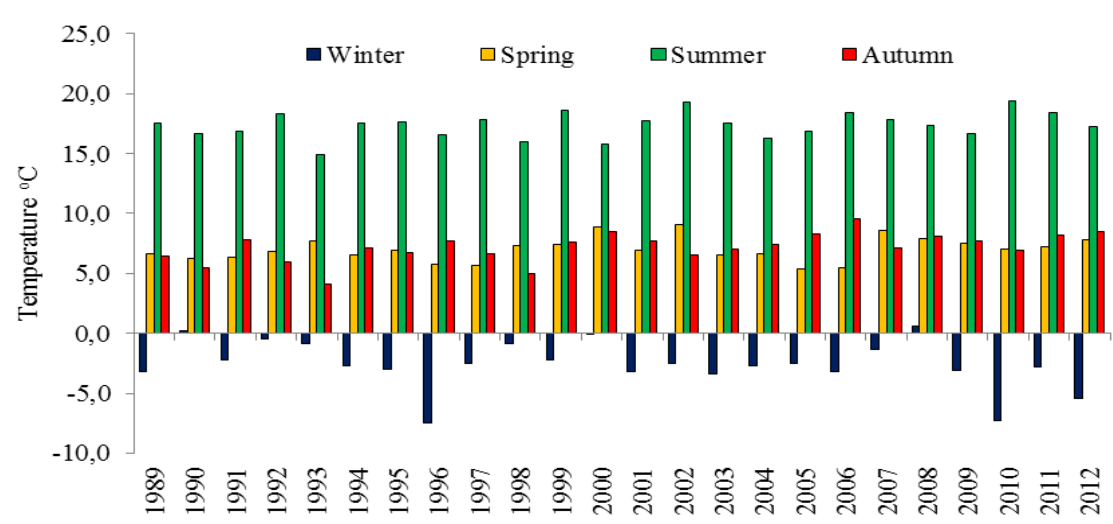

Fig. 2. Average seasonal air temperature

While analysing the data of 1989-2012 in the researched territory, it is determined that the lowest quantity of precipitation is in spring (22\%) and the highest quantity of precipitation is in summer (even 34.5\%) and autumn (25\%) (Fig. 3). During research period the drainage runoff in the field I was highest during winter (46\%), in spring - 43\% and the lowest in summer (2\%), in the field II - the drainage runoff was almost equal in winter and spring (32-33\%) and the lowest - also in summer.

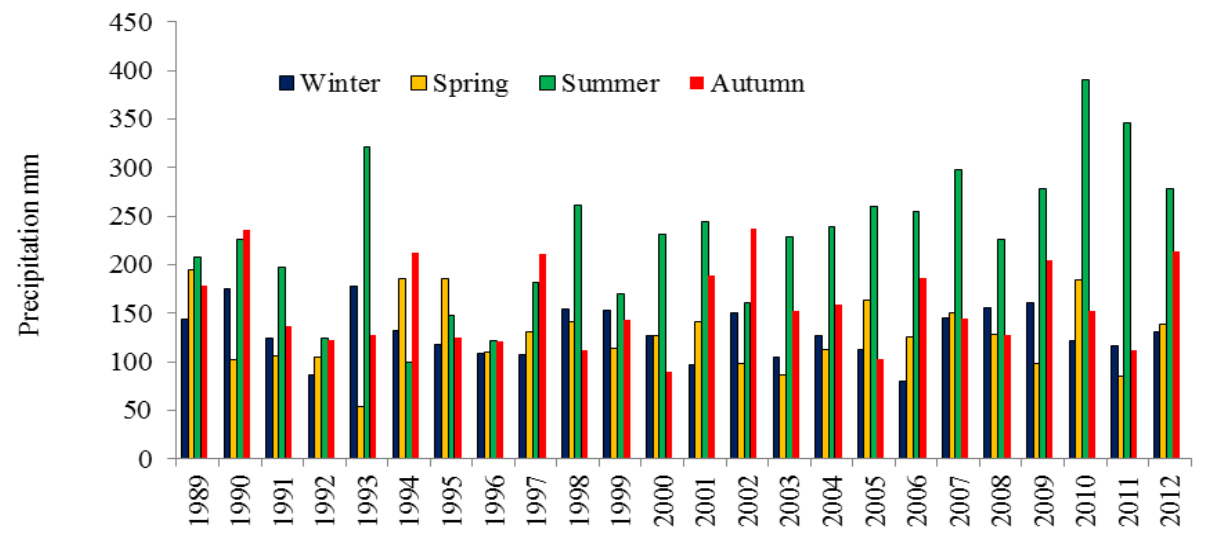

Fig. 3. Average seasonal quantity of precipitation

Thus, regulated drainage may help the plants to provide with water, since they often lack moisture. After carrying out research Ramoška et al. (2006) determined that the nature of drainage activity generally had no impact on water level of soil in the gap between drains. The analysis of runoff observation data revealed that seasonality, typical for run-off change, remains: during spring March and April - the average runoff is the highest but the lowest in the summer season - July and August, while in May, June and August - almost the same. According (Miseckaite, 2014) a statistically significant trend of increase of 
annual drainage runoff was found during winter season, while there is no statistically significant trend for annual precipitation, the trend is very slightly increasing.

The field with the thickened humus content drainage runoff ranged higher amplitude than the field in all seasons, with a natural layer of humus. Statistically significant results were obtained in winter and spring ( $<<0.05$, Fig. 4).

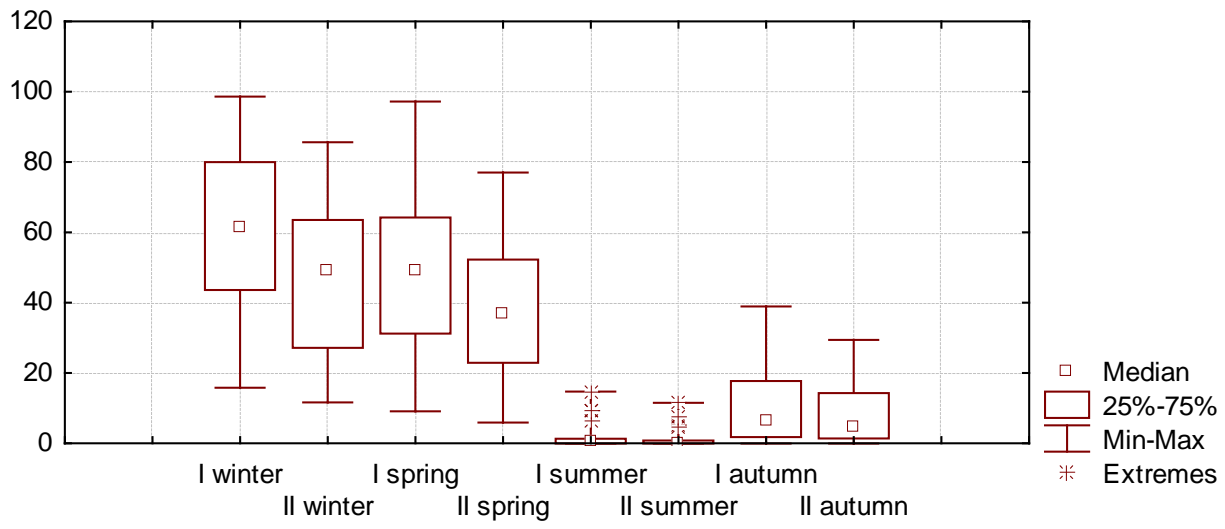

Fig. 4. Drainage runoff distribution during different seasons of research period

When studying relations between drainage runoff in different seasons it was determined that in bold thick (field No. I) in winter there was an average link $(\mathrm{r}=0.5, \mathrm{p}<0.05)$, and in other seasons - the inter-relation was weak (in spring and autumn ( $\mathrm{r}=0.4, \mathrm{r}=0.3$ ), and very weak in summer $(\mathrm{r}=0.1)$. In natural layer (II) there was an average link in winter too $(\mathrm{r}=0.6, \mathrm{p}<0.05)$ and in spring $(\mathrm{r}=0.5$, $\mathrm{p}<0.05$ ), the inter-relation was very weak in summer ( $\mathrm{r}=0.1)$ and the inter-relation was weak in autumn ( $r=0.3)$. Tendency of trends decrease can be seen in spring in both fields. Thus, the drainage runoff in the field with thin humus layer has a greater impact compared to the one with the thickened humus layer.

\section{CONCLUSIONS}

Analysing the annual drainage runoff during a twenty-three year period between the annual values outside with the artificially thickened humus content (up to $50 \mathrm{~cm}$ ) and in the control field, with natural humus content (up to $30 \mathrm{~cm}$ ), a statistically significant difference $(\mathrm{p}<0.05)$ was defined..

The size of drainage runoff is mostly influenced by amount of precipitation $(\mathrm{r}=0.49-0.46)$. In case of thickened humus layer, statistically reliable result was obtained. In case of thickened humus layer annual drainage runoff was approximately $21 \%$ of annual precipitation quantity, when natural humus layer was approximately $16 \%$.

Increased humus quantity has statistically significantly increased the drainage runoff during winter and spring seasons $(\mathrm{p}<0.05)$. 


\section{REFERENCES}

Buciene A, Antanaitis A, Masauskiene A, Simanskaite D. (2007). Nutrients N, P losses with drainage runoff and field balance as a result of crop management. Commun Soil Sci Plan, Vol. 38 (No. 15, 16), p. 2177-2195.

Bukantis A., Rimkus E. (2005). Climate variability and change in Lithuania. Acta Zoologica Lituanica, Vol. 15 (No. 2), p. 100-104.

Celik H., Katkat V., Asik B. B., Turan A. A. (2010). Effects of humus on growth and nutrient uptake of maize under saline and calcareous soil conditions. Zemdirbyste-Agriculture, Vol. 97 (No. 4), p. 15-22.

Knezevic M., Durovic D., Mugosa B., Strunjas M., Topalovic A. (2014). Relationships between parameters of soil and chard (Beta Vulgaris L. Var. Cicla L.). Agriculture \& Forestry, Vol. 60 (No. 3), p. 275-283.

Kupcinskas V., Baniunienè A., Zekaite V., Sidlauskas G. (2003). Mineralinių ir organinių trąšu bei meteorologinių sąlygų įtaka bulvių produktyvumui priesmèlio dirvoje (Influence of mineral and organic fertilizers and meteorological conditions on the productivity of potato in sandy loam soil) Žemdirbystè. LŽI ir LŽŪU mokslo darbai, Vol. 84 (No. 4), p. 23-34.

Miseckaite O. (2014). The influence of climate change on water regime in drainage land. Agriculture \& Forestry, Vol. 60 (No. 4), p. 29-34.

Nearing M. A., Pruski F. F., O`Neal M. R. (2004). Expected climate change impacts on soil erosion rates: a review. Journal of Soil and Water Conservation, Vol. 59 (No. 1), p. 43-50.

Oenema O., Heinen M. (1999). Uncertainties in nutrient budget due to biases and errors in Nutrient Disequilibria in Agroecosystems: Concepts and Case Studies, E. M. A. Smaling, O. Oenema, L. O. Fresco, Eds., pp. 75-97, CAB International, Wallingford, UK.

Povilaitis A., Lamsodis R., Bastienè N., Rudzianskaite A., Misevičienè S., Miseckaite O., Guzys S., Baigys G., Grybauskienė V., Balevicius G. (2015). Agricultural drainage in Lithuania: a review of practices and environmental effects. Acta Agriculturae Scandinavica, Section B - Soil \& Plant Science, Vol. 65 (No. 1), p. 14-29.

Ramoška E., Morkūnas V. (2006). Drenažo nuotèkio reguliavimo įtaka dirvožemio vandens režimui (Influence of drainage runoff regulation on soil water regime). Vandens ukio inzinerija, Vol. 30 (No. 50), p. 5-14.

Sims J. T., Simard R. R., Joer B. C. (1998). Phosphorus Loss in Agricultural Drainage: Historical Perspective and Current Research. Journal of Environmental Quality, Vol 27 (No. 2), p. 277-293.

Turunen M., Warsta L., Paasonen-Kivekas M., Nurminen J., Koivusalo H. (2015). Simulating water balance and evapotranspiration in a subsurface drained clayey agricultural field in high-latitude conditions. Acta Agriculturae Scandinavica, Section B - Soil \& Plant Science, Vol. 65 (No. 1), p. 44-57. 